\title{
Hydrogen Storage Properties of Pure $\mathrm{MgH}_{2}$
}

\author{
Young Jun Kwak, Seong Ho Lee, Hye Ryoung Park* and Myoung Youp Song**† \\ Department of Materials Engineering, Graduate School, Chonbuk National University, \\ 567 Baekje-daero Deokjin-gu, Jeonju 561-756, Korea \\ *Faculty of Applied Chemical Engineering, Chonnam National University, 77 Yongbong-ro Buk-gu, \\ Gwangju 500-757, Korea \\ **Division of Advanced Materials Engineering, Department of Hydrogen and Fuel Cells, \\ Hydrogen \& Fuel Cell Research Center, Engineering Research Institute, Chonbuk National University, \\ 567 Baekje-daero Deokjin-gu, Jeonju 561-756, Korea
}

(Received March 11, 2013 : Received in revised form April 17, 2013 : Accepted April 18, 2013)

\begin{abstract}
The hydrogen storage properties of pure $\mathrm{MgH}_{2}$ were studied and compared with those of pure $\mathrm{Mg}$. At the first cycle, pure $\mathrm{MgH}_{2}$ absorbed hydrogen very slowly at $573 \mathrm{~K}$ under 12 bar $\mathrm{H}_{2}$. The activation of pure $\mathrm{MgH}_{2}$ was completed after three hydriding-dehydriding cycles. At the $4^{\text {th }}$ cycle, the pure $\mathrm{MgH}_{2}$ absorbed $1.55 \mathrm{wt} \% \mathrm{H}$ for $5 \mathrm{~min}, 2.04 \mathrm{wt} \% \mathrm{H}$ for $10 \mathrm{~min}$, and $3.59 \mathrm{wt} \% \mathrm{H}$ for $60 \mathrm{~min}$, showing that the activated $\mathrm{MgH}_{2}$ had a much higher initial hydriding rate and much larger $\mathrm{H}_{\mathrm{a}}(60$ $\mathrm{min}$ ), quantity of hydrogen absorbed for $60 \mathrm{~min}$, than did activated pure $\mathrm{Mg}$. The activated pure $\mathrm{Mg}$, whose activation was completed after four hydriding-dehydriding cycles, absorbed $0.80 \mathrm{wt} \% \mathrm{H}$ for $5 \mathrm{~min}, 1.25 \mathrm{wt} \% \mathrm{H}$ for $10 \mathrm{~min}$, and $2.34 \mathrm{wt} \%$ $\mathrm{H}$ for $60 \mathrm{~min}$. The particle sizes of the $\mathrm{MgH}_{2}$ were much smaller than those of the pure $\mathrm{Mg}$ before and after hydridingdehydriding cycling. The pure $\mathrm{Mg}$ had larger hydrogen quantities absorbed at $573 \mathrm{~K}$ under 12 bar $\mathrm{H}_{2}$ for $60 \mathrm{~min}, \mathrm{H}_{\mathrm{a}}(60 \mathrm{~min})$, than did the pure $\mathrm{MgH}_{2}$ from the number of cycles $n=1$ to $n=3$; however, the pure $\mathrm{MgH}_{2}$ had larger $\mathrm{H}_{\mathrm{a}}(60 \mathrm{~min})$ than did the pure $\mathrm{Mg}$ from $\mathrm{n}=4$ to $\mathrm{n}=6$.
\end{abstract}

Key words pure magnesium hydride, pure magnesium, hydriding rate, microstructure, X-ray diffraction.

\section{Introduction}

Magnesium has advantages as a hydrogen storage material from the viewpoints of hydrogen storage capacity, cost and reserves in the earth's crust. However, its reaction rate with $\mathrm{H}_{2}$ is very low. ${ }^{1)}$

Song's review ${ }^{2)}$ on the kinetic studies of the hydriding and the dehydriding reactions of $\mathrm{Mg}$ reported that the hydriding and dehydriding reactions of $\mathrm{Mg}$ are nucleationcontrolled under certain conditions and progress by a mechanism of nucleation and growth, and that the hydriding rates of $\mathrm{Mg}$ are controlled by the diffusion of hydrogen through a growing $\mathrm{Mg}$ hydride layer.

By use of the first-principles density functional theory for a cluster model, the alloying effect of transition element $\mathrm{M}$ on the electronic structure of magnesium hydride, $\mathrm{MgH}_{2}$, was investigated by Chen et al. ${ }^{3)}$. They concluded that the chemical interaction between $\mathrm{Mg}$ and $\mathrm{H}$ may play a dominant role in the pure $\mathrm{MgH}_{2}$ system. Such a strong interaction remained in the alloyed $\mathrm{Mg}(\mathrm{M}) \mathrm{H}_{2}$ when the central $\mathrm{Mg}$ was replaced by an alloying element $\mathrm{M}$. By a satisfactory fit of the calculated $\mathrm{M}$ (or $\mathrm{Mg}$ )- $\mathrm{H}$ interactions with the enthalpies of formation for some pure dihydrides, they reported that $70 \%$ chemical (ionic plus covalent) interactions would appear to be ionic but the covalent interaction of an adjacent $\mathrm{Mg}$ to $\mathrm{M}$ with a $\mathrm{H}$ atom around it would be sensitive to the substitution of $\mathrm{M}$.

The paper of Matovic et al. ${ }^{4)}$ dealt with non-isothermal kinetics models of hydrogen desorption from $\mathrm{MgH}_{2}$ altered by ion bombardment and stressed the importance of the $\mathrm{MgH}_{2}$ surface during its decomposition. In the case of argon-irradiated samples, where defects were induced in the near-surface region, the Avrami Erofeev mechanism with parameter $n=2$ could be adopted while in the case of

\footnotetext{
${ }^{\dagger}$ Corresponding author

E-Mail : songmy@jbnu.ac.kr (M. Y. Song, Chonbuk Nat'l Univ.)
}

(C) Materials Research Society of Korea, All rights reserved.

This is an Open-Access article distributed under the terms of the Creative Commons Attribution Non-Commercial License (http://creativecommons.org/licenses/by-nc/3.0) which permits unrestricted non-commercial use, distribution, and reproduction in any medium, provided the original work is properly cited. 
boron-irradiated samples, where defects were created deeper in the bulk, the desorption mechanism was the same with $n=3$. The difference was possibly related to the concentration and good dispersion of defects in nearsurface region in the samples.

A lot of work to improve the hydriding and dehydriding rates of magnesium has been performed by alloying with magnesium metals ${ }^{5,6)}$ such as $\mathrm{Cu},{ }^{7)} \mathrm{Ni},{ }^{8,9)} \mathrm{In},{ }^{10)} \mathrm{Sn},{ }^{11)} \mathrm{V},{ }^{12)}$ and $\mathrm{Ni}$ and $\mathrm{Y}^{13}{ }^{13}$ by synthesizing compounds such as $\mathrm{CeMg}_{12}{ }^{14)}$ and $\mathrm{Mg}_{76} \mathrm{Ti}_{12} \mathrm{Fe}_{12-\mathrm{x}} \mathrm{Ni}_{\mathrm{x}}(\mathrm{x}=4,8),{ }^{15)}$ and by making composites such as $\mathrm{Mg}-20 \mathrm{wt} \% \mathrm{Fe}_{23} \mathrm{Y}_{8}{ }^{16)}$ Aminorroaya et al. ${ }^{17)}$ added $\mathrm{Nb}$ and multi-walled carbon nanotubes to Mg-Ni alloys, and Cho et al. ${ }^{18)}$ added transition metals to cast $\mathrm{Mg}-\mathrm{Ni}$ alloys for the improvement of the reaction rates of $\mathrm{Mg}$ with $\mathrm{H}_{2}$. Milanese et al. ${ }^{19)}$ mixed $\mathrm{Ni}$ and $\mathrm{Cu}$ with $\mathrm{Mg}$, Tanguy et al. ${ }^{20)}$ mixed metal additives with magnesium, and Eisenberg et al. ${ }^{21)}$ plated nickel on the surface of magnesium to improve the hydriding-dehydriding kinetics of $\mathrm{MgH}_{2}$.

Mao et al. ${ }^{22)}$ investigated doping $\mathrm{MgH}_{2}$ with $\mathrm{NiCl}_{2}$ and $\mathrm{CoCl}_{2}$ in an effort to develop $\mathrm{MgH}_{2}$ with a low dehydriding temperature and fast sorption kinetics. Both the dehydrogenation temperature and the absorption/desorption kinetics were improved by adding either $\mathrm{NiCl}_{2}$ or $\mathrm{CoCl}_{2}$, and a significant enhancement was obtained in the case of the $\mathrm{NiCl}_{2}$ doped sample.

The paper of Cermak and David ${ }^{23)}$ investigated separate catalytic effects of $\mathrm{Ni}, \mathrm{Mg}_{2} \mathrm{Ni}$ and $\mathrm{Mg}_{2} \mathrm{NiH}_{4}$ on the hydrogen desorption characteristics of $\mathrm{MgH}_{2}$. It was observed that the catalytic efficiency of $\mathrm{Mg}_{2} \mathrm{NiH}_{4}$ was considerably higher than that of pure $\mathrm{Ni}$ and non-hydrated intermetallic $\mathrm{Mg}_{2} \mathrm{Ni}$.

As shown in these examples, the hydrogen absorption and desorption behaviors of $\mathrm{Mg}$ have been studied by using pure $\mathrm{Mg}$ or pure $\mathrm{MgH}_{2}$ as a starting material. The pure $\mathrm{MgH}_{2}$ is more difficult to synthesize and more expensive than the pure $\mathrm{Mg}$. By comparing the hydrogen absorption and desorption behaviors and the prices, it is necessary to determine which is appropriate to be used as a starting material.

In this work, hydrogen storage properties of the pure $\mathrm{MgH}_{2}$ were studied and compared with those of the pure Mg.

\section{Experimental details}

Pure $\mathrm{MgH}_{2}$ powder (hydrogen storage grade, Aldrich) and pure $\mathrm{Mg}$ powder $(-100+200$ mesh, $99.6 \%$, Alfa Aesar) were used.

The absorbed or desorbed hydrogen quantity was measured as a function of time by a volumetric method, using a Sivert's type hydriding and dehydriding apparatus described previously. ${ }^{24)} 0.5 \mathrm{~g}$ of the samples was used for these measurements. Samples after reactive mechanical grinding and those after hydriding-dehydriding cycling were characterized by X-ray diffraction (XRD) with $\mathrm{Cu}$ $\mathrm{K} \alpha$ radiation, using a Rigaku D/MAX 2500 powder diffractometer. The microstructures of the powders were observed by a JSM-6400 scanning electron microscope (SEM) operated at $20 \mathrm{kV}$.

\section{Results and discussion}

The percentage of absorbed hydrogen, $\mathrm{H}_{\mathrm{a}}$, is expressed with respect to sample weight. Fig. 1 shows the variation of the $\mathrm{H}_{\mathrm{a}}$ versus $\mathrm{t}$ curve with the number of cycles, $n$, for the pure $\mathrm{Mg}$ at $573 \mathrm{~K}$ under $12 \mathrm{bar}_{2}$. The pure $\mathrm{Mg}$ absorbs hydrogen very slowly. At $\mathrm{n}=1$, pure Mg absorbs $0.05 \mathrm{wt} \% \mathrm{H}$ for $5 \mathrm{~min}, 0.08 \mathrm{wt} \% \mathrm{H}$ for $10 \mathrm{~min}, 0.17 \mathrm{wt} \%$ $\mathrm{H}$ for $30 \mathrm{~min}$, and $0.29 \mathrm{wt} \% \mathrm{H}$ for $60 \mathrm{~min}$. The quantity of hydrogen absorbed for $60 \mathrm{~min}$ is expressed by $\mathrm{H}_{\mathrm{a}}(60$ $\min )$. The initial hydriding rate and $\mathrm{H}_{\mathrm{a}}(60 \mathrm{~min})$ increase as the number of cycles increases from $n=1$ to $n=5$, and then decrease as the number of cycles increases from $n=$ 5 to $n=6$, showing that the activation of the pure $\mathrm{Mg}$ was completed after four hydriding-dehydriding cycles. At $\mathrm{n}=$ 5, pure $\mathrm{Mg}$ absorbs $0.80 \mathrm{wt} \% \mathrm{H}$ for $5 \mathrm{~min}, 1.25 \mathrm{wt} \% \mathrm{H}$ for $10 \mathrm{~min}, 1.94 \mathrm{wt} \% \mathrm{H}$ for $30 \mathrm{~min}$, and $2.34 \mathrm{wt} \% \mathrm{H}$ for 60 min.

Dehydriding rate at $573 \mathrm{~K}$ under 1.0 bar $\mathrm{H}_{2}$ was too low to be measured, and thus the sample was dehydrided at $623 \mathrm{~K}$ in vacuum for $2 \mathrm{~h}$ for the hydrogen absorption measurement at the next cycle.

The SEM micrographs of the pure $\mathrm{Mg}$ and the pure $\mathrm{Mg}$ dehydrided at the $10^{\text {th }}$ hydriding-dehydriding cycle are shown in Fig. 2. The particle of the pure Mg has a few cracks with quite flat surface. In the pure Mg dehydrided at the $10^{\text {th }}$ hydriding-dehydriding cycle, defects

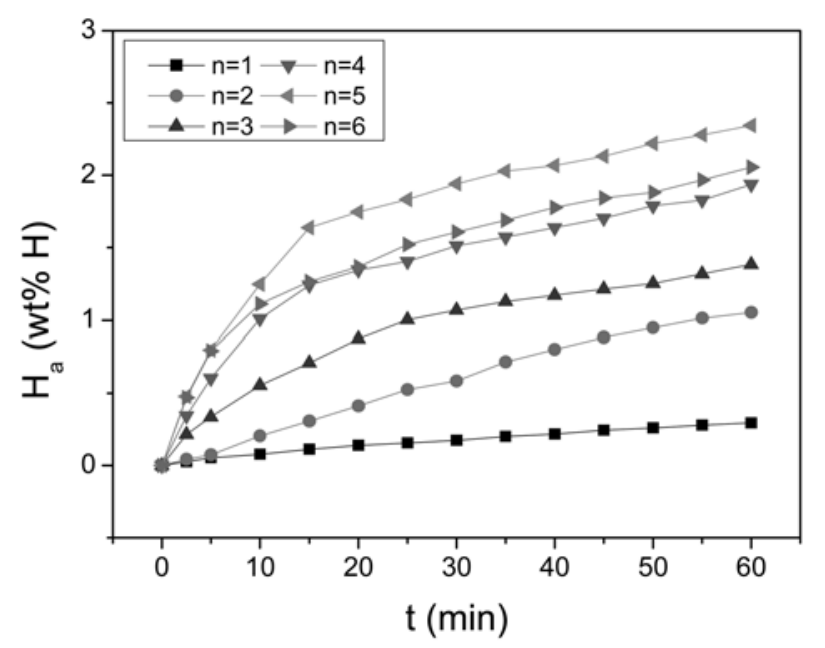

Fig. 1. Variation of the $H_{a}$ versus $t$ curve with the number of cycles, $\mathrm{n}$, for pure $\mathrm{Mg}$ at $573 \mathrm{~K}$ under 12 bar $\mathrm{H}_{2}$. 

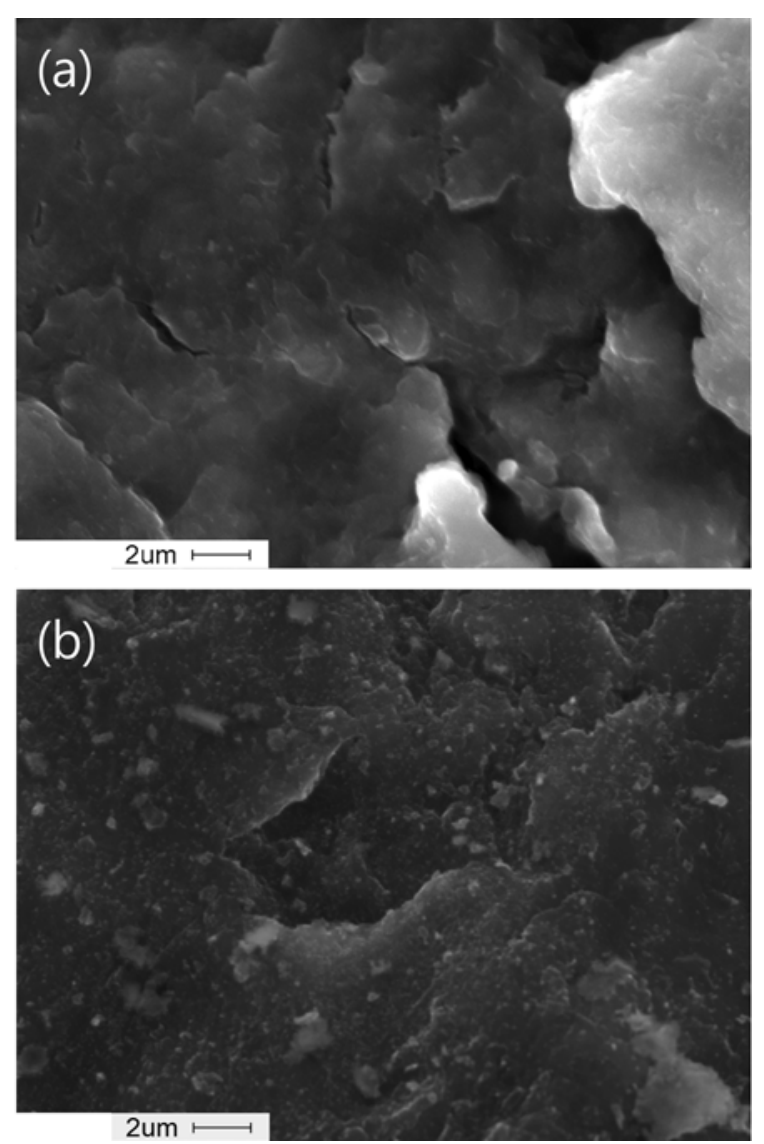

Fig. 2. SEM micrographs of (a) the pure $\mathrm{Mg}$, and (b) the pure $\mathrm{Mg}$ dehydrided at the $10^{\text {th }}$ hydriding-dehydriding cycle.

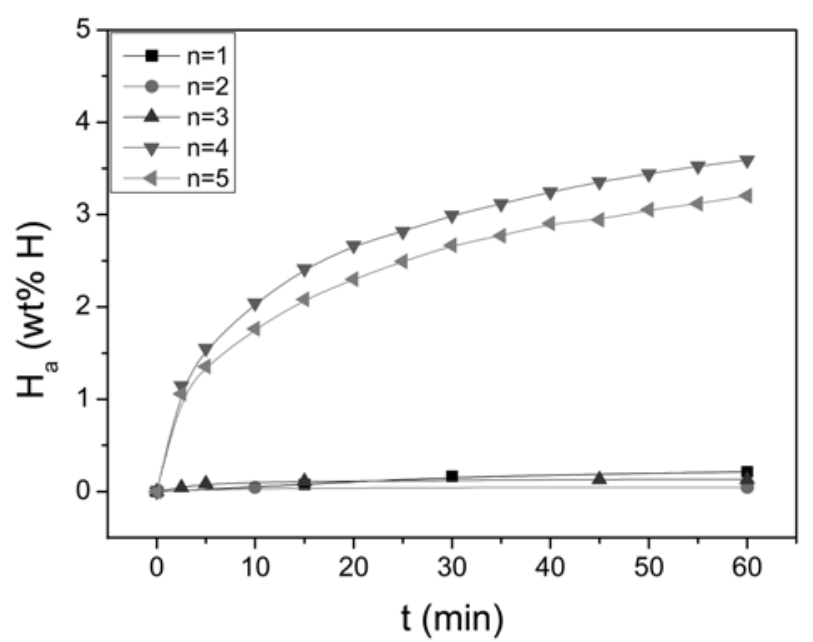

Fig. 3. Variation of the $\mathrm{H}_{\mathrm{a}}$ versus $\mathrm{t}$ curve with the number of cycles for the pure $\mathrm{MgH}_{2}$ at $573 \mathrm{~K}$ under 12 bar $\mathrm{H}_{2}$.

are created with hydriding-dehydriding cycling. The expansion and contraction of $\mathrm{Mg}$ with the hydriding and dehydriding reactions is considered to create defects.

Fig. 3 shows the variation of the $\mathrm{H}_{\mathrm{a}}$ versus $t$ curve with the number of cycles, $\mathrm{n}$, for the pure $\mathrm{MgH}_{2}$ at $573 \mathrm{~K}$
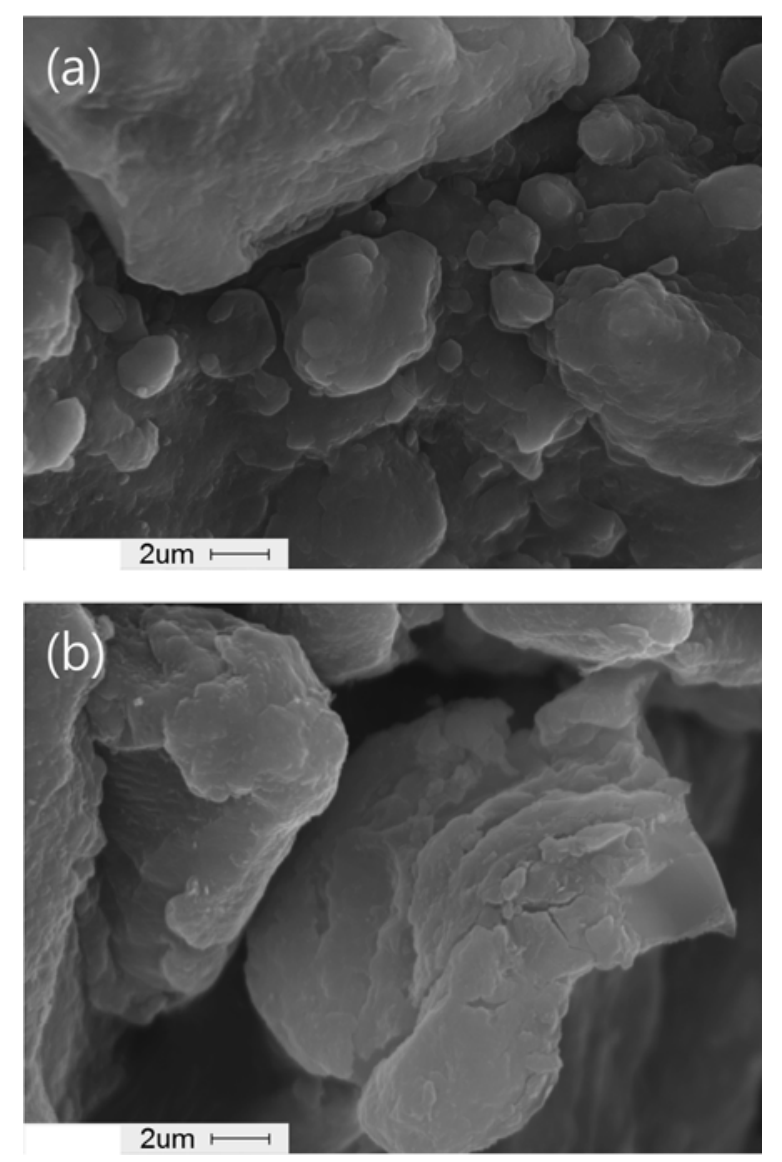

Fig. 4. SEM micrographs of (a) the pure $\mathrm{MgH}_{2}$, and (b) the pure $\mathrm{MgH}_{2}$ dehydrided at the $7^{\text {th }}$ hydriding-dehydriding cycle.

under 12 bar $\mathrm{H}_{2}$. At $\mathrm{n}=1$, the sample absorbs hydrogen very slowly. The initial hydriding rate and $\mathrm{H}_{\mathrm{a}}(60 \mathrm{~min})$ of the $\mathrm{MgH}_{2}$ increase as the number of cycles increases from $n=1$ to $n=4$, and decrease as the number of cycles increases from $n=4$ to $n=5$, showing that the activation of the pure $\mathrm{MgH}_{2}$ was completed after three hydridingdehydriding cycles. At $\mathrm{n}=4$, the $\mathrm{MgH}_{2}$ absorbs $1.55 \mathrm{wt} \%$ $\mathrm{H}$ for $5 \mathrm{~min}, 2.04 \mathrm{wt} \% \mathrm{H}$ for $10 \mathrm{~min}, 2.99 \mathrm{wt} \% \mathrm{H}$ for 30 $\mathrm{min}$, and $3.59 \mathrm{wt} \% \mathrm{H}$ for $60 \mathrm{~min}$, showing that the $\mathrm{MgH}_{2}$ has a much higher hydriding rate than the activated pure $\mathrm{Mg}$. The increase in the initial hydriding rate and $\mathrm{H}_{\mathrm{a}}(60$ $\min$ ) with cycling from $n=1$ to $n=3$ are low, but they are high from $n=4$ to $n=6$. The particle expands during hydriding and contracts during dehydriding. For the first two hydriding-dehydriding cycles, the formation of cracks and the deminution of particle size due to expansion and contraction of particles may occur weakly, but they occur probably strongly at the $3^{\text {rd }}$ hydriding-dehydriding cycle, leading to the high hydriding rate.

The SEM micrographs of the pure $\mathrm{MgH}_{2}$ and the pure $\mathrm{MgH}_{2}$ dehydrided at the $7^{\text {th }}$ hydriding-dehydriding cycle are shown in Fig. 4. The pure $\mathrm{MgH}_{2}$ has small and large particles with quite flat surfaces. The particle size of the 


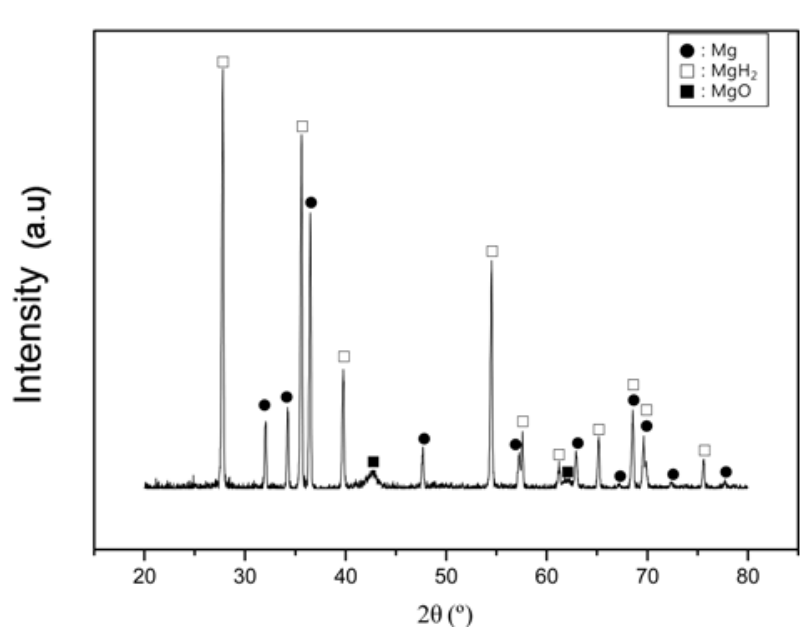

Fig. 5. XRD pattern of the pure $\mathrm{MgH}_{2}$ dehydrided at the $7^{\text {th }}$ hydriding-dehydriding cycle.

pure $\mathrm{MgH}_{2}$ is much smaller than that of the pure Mg. In the pure $\mathrm{MgH}_{2}$ dehydrided at the $7^{\text {th }}$ hydriding-dehydriding cycle, defects are created with hydriding-dehydriding cycling. The expansion and contraction of $\mathrm{Mg}$ with the hydriding and dehydriding reactions is considered to make defects. The particle size of the pure $\mathrm{MgH}_{2}$ after hydridingdehydriding cycling is similar to that of the pure $\mathrm{MgH}_{2}$ before hydriding-dehydriding cycling. The particle size of the pure $\mathrm{MgH}_{2}$ after hydriding-dehydriding cycling is smaller than that of the pure $\mathrm{Mg}$ after hydriding-dehydriding cycling. This is resulted partly from the point that the initial particle size (before hydriding-dehydriding cycling) of $\mathrm{MgH}_{2}$ was smaller than that of the pure $\mathrm{Mg}$.

Fig. 5 shows the XRD pattern of the pure $\mathrm{MgH}_{2}$ dehydrided at the $7^{\text {th }}$ hydriding-dehydriding cycle. The sample contains $\mathrm{Mg}$, a small amount of $\mathrm{MgO}$ and a large amount of $\mathrm{MgH}_{2}$, indicating that a large fraction of $\mathrm{MgH}_{2}$ remains even after dehydriding in vacuum at $623 \mathrm{~K}$ for $2 \mathrm{~h}$, and showing that the dehydriding rate of the pure $\mathrm{MgH}_{2}$ is very low.

Variations of the hydrogen quantity absorbed at $573 \mathrm{~K}$ under 12 bar $\mathrm{H}_{2}$ for $60 \mathrm{~min}, \mathrm{H}_{\mathrm{a}}(60 \mathrm{~min})$, with the number of cycles from 1 to 6 for the pure $\mathrm{Mg}$ and the pure $\mathrm{MgH}_{2}$ are shown in Fig. 6. The value of $\mathrm{H}_{\mathrm{a}}(60 \mathrm{~min})$ for the pure $\mathrm{Mg}$ increases as the number of cycles increases from $\mathrm{n}=$ 1 to $n=5$, and decreases from $n=5$ to $n=6$. The values of $\mathrm{H}_{\mathrm{a}}(60 \mathrm{~min})$ for the pure $\mathrm{Mg}$ are $0.29,2.34$, and 2.06 $\mathrm{wt} \% \mathrm{H}$ at $\mathrm{n}=1,5$, and 6 , respectively. The value of $\mathrm{H}_{\mathrm{a}}$ (60 min) for the pure $\mathrm{MgH}_{2}$ increases as the number of cycles increases from $n=1$ to $n=4$, and decreases from $\mathrm{n}=4$ to $\mathrm{n}=6$. The values of $\mathrm{H}_{\mathrm{a}}(60 \mathrm{~min})$ for the pure $\mathrm{MgH}_{2}$ are $0.22,3.59$, and $3.24 \mathrm{wt} \% \mathrm{H}$ at $\mathrm{n}=1,4$, and 6 , respectively. The pure $\mathrm{Mg}$ has larger values of $\mathrm{H}_{\mathrm{a}}(60 \mathrm{~min})$ than the pure $\mathrm{MgH}_{2}$ from $\mathrm{n}=1$ to $\mathrm{n}=3$, but the pure $\mathrm{MgH}_{2}$ has larger values of $\mathrm{H}_{\mathrm{a}}(60 \mathrm{~min})$ than the pure $\mathrm{Mg}$ from $\mathrm{n}=4$ to $\mathrm{n}=6$.

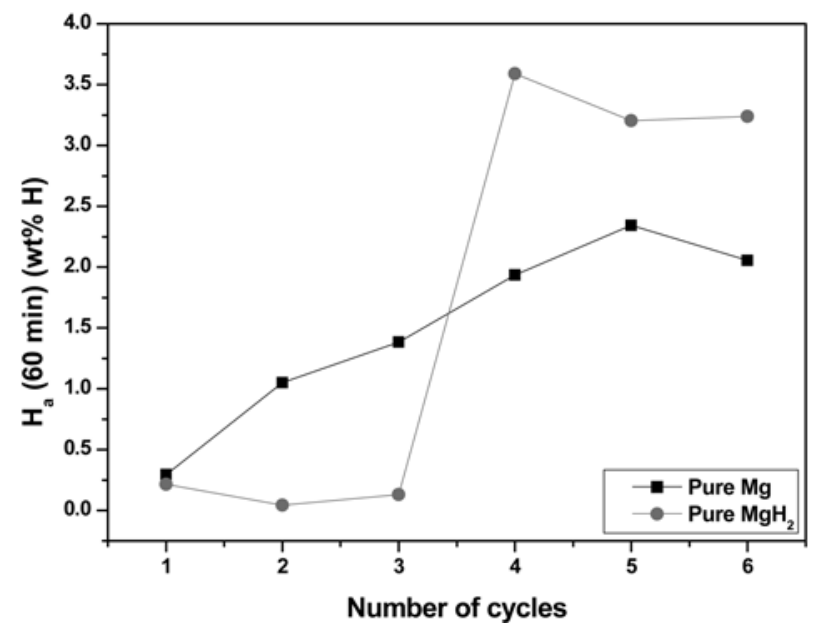

Fig. 6. Variations of hydrogen quantity absorbed at $573 \mathrm{~K}$ under 12 bar $\mathrm{H}_{2}$ for $60 \mathrm{~min}$, $\mathrm{Ha}(60 \mathrm{~min})$, with the number of cycles from 1 to 6 for the pure $\mathrm{Mg}$ and the pure $\mathrm{MgH}_{2}$.

The pure $\mathrm{MgH}_{2}$ dehydrided at the $7^{\text {th }}$ hydriding-dehydriding cycle contains $\mathrm{Mg}$, a small amount of $\mathrm{MgO}$ and a large amount of $\mathrm{MgH}_{2}$ (Fig. 5). Since $\mathrm{MgH}_{2}$ remains before hydriding measurement, the nuclei of $\mathrm{MgH}_{2}$ are present before hydriding measurement. Before hydridig measurement, more $\mathrm{MgH}_{2}$ remained in the pure $\mathrm{MgH}_{2}$ than in the pure Mg. Fig. 2(b) and Fig. 4(b) show that the particle size of the pure $\mathrm{MgH}_{2}$ after hydriding-dehydriding cycling is smaller than that of the pure $\mathrm{Mg}$ after hydridingdehydriding cycling. The larger content of $\mathrm{MgH}_{2}$ (thus the larger content of $\mathrm{MgH}_{2}$ nuclei) and the smaller particle size of the pure $\mathrm{MgH}_{2}$ are believed to lead to the higher initial hydriding rate and larger $\mathrm{H}_{\mathrm{a}}(60 \mathrm{~min})$ of the pure $\mathrm{MgH}_{2}$ than the pure $\mathrm{Mg}$.

\section{Conclusions}

At the first cycle, the pure $\mathrm{MgH}_{2}$ absorbed hydrogen

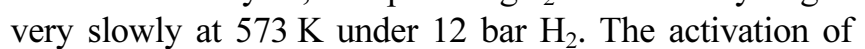
the pure $\mathrm{MgH}_{2}$ was completed after three hydriding-dehydriding cycles. At the $4^{\text {th }}$ cycle, the pure $\mathrm{MgH}_{2}$ absorbed $1.55 \mathrm{wt} \% \mathrm{H}$ for $5 \mathrm{~min}, 2.04 \mathrm{wt} \% \mathrm{H}$ for $10 \mathrm{~min}$, and $3.59 \mathrm{wt} \% \mathrm{H}$ for $60 \mathrm{~min}$, showing that the activated $\mathrm{MgH}_{2}$ had a much higher initial hydriding rate and a much larger $\mathrm{H}_{\mathrm{a}}(60 \mathrm{~min})$ than the activated pure $\mathrm{Mg}$. The activated pure $\mathrm{Mg}$, whose activation was completed after four hydriding-dehydriding cycles, absorbed $0.80 \mathrm{wt} \% \mathrm{H}$ for 5 $\min , 1.25 \mathrm{wt} \% \mathrm{H}$ for $10 \mathrm{~min}$, and $2.34 \mathrm{wt} \% \mathrm{H}$ for 60 min. The particle sizes of the pure $\mathrm{MgH}_{2}$ before and after hydriding-dehydriding cycling were much smaller than those of the pure $\mathrm{Mg}$ before and after hydriding-dehydriding cycling. The pure $\mathrm{Mg}$ had larger values of $\mathrm{H}_{\mathrm{a}}(60$ min) than the pure $\mathrm{MgH}_{2}$ from the number of cycles $n=1$ to $n=3$, but the pure $\mathrm{MgH}_{2}$ had larger values of $\mathrm{H}_{\mathrm{a}}$ 
(60 min) than the pure $\mathrm{Mg}$ from $\mathrm{n}=4$ to $\mathrm{n}=6$.

\section{Acknowledgement}

This research was supported by Basic Science Research Program through the National Research Foundation (NRF) of Korea funded by the Ministry of Education, Science and Technology (Grant number 2011-0023566).

This work was also supported by the selection of research oriented professor of Chonbuk National University in 2013.

\section{References}

1. M. Y. Song, Y. J. Kwak, B. S. Lee, H. R. Park and B. G. Kim, Korean J. Met. Mater., 49(12), 989 (2011).

2. M. Y. Song, J. Mater. Sci., 30, 1343 (1995).

3. D. Chen, Y. M. Wang, L. Chen, S. Liu, C. X. Ma, L. B. Wang, Acta Materialia, 52(2), 521 (2004).

4. L. Matović, S. Kurko, Ž. Rašković-Lovre, R. Vujasin, I. Milanović, S. Milošević, J. Grbović Novaković, Int. J. Hydrogen Energy, 37(8), 6727 (2012).

5. S. H. Hong, S. N. Kwon, and M. Y. Song, Korean J. Met. Mater., 49(4), 298 (2011).

6. K. I. Kim and T. W. Hong, Korean J. Met. Mater., 49(3), 264 (2011).

7. J. J. Reilly and R. H. Wiswall, Inorg. Chem., 6(12), 2220 (1967).

8. J. J. Reilly and R. H. Wiswall Jr, Inorg. Chem., 7(11), 2254 (1968).

9. E. Akiba, K. Nomura, S. Ono and S. Suda, Int. J. Hydrogen Energy, 7(10), 787 (1982).
10. M. H. Mintz, Z. Gavra and Z. Hadari, J. Inorg. Nucl. Chem., 40, 765 (1978).

11. H. C. Zhong, H. Wang, L. Z. Ouyang, M. Zhu, J. Alloy Compd., 509(11), 4268 (2011).

12. P. Pei, X. Song, J. Liu, A. Song, P. Zhang, G. Chen, Int. J. Hydrogen Energy, 37(1), 984 (2012).

13. Z. Li, X. Liu, L. Jiang, S. Wang, Int. J. Hydrogen Energy, 32(12), 1869 (2007).

14. J. M. Boulet and N. Gerard, J. Less-Common Met., 89, 151 (1983).

15. M. Lucaci, Al. R. Biris, R. L. Orban, G. B. Sbarcea, V. Tsakiris, J. Alloys Compd., 488(1), 163 (2009).

16. Z. Li, X. Liu, Z. Huang, L. Jiang, S. Wang, Rare Metals, 25(6)(Supplement 1), (247) 2006.

17. S. Aminorroaya, A. Ranjbar, Y. H. Cho, H. K. Liu, A. K. Dahle, Int. J. Hydrogen Energy, 36(1), 571 (2011).

18. Y. H. Cho, S. Aminorroaya, H. K. Liu, A. K. Dahle, Int. J. Hydrogen Energy, 36(8), 4984 (2011).

19. C. Milanese, A. Girella, G. Bruni, P. Cofrancesco, V. Berbenni, P. Matteazzi, A. Marini, Intermetallics, 18(2), 203 (2010).

20. B. Tanguy, J. L. Soubeyroux, M. Pezat, J. Portier and P. Hagenmuller, Mater. Res. Bull., 11, 1441(1976).

21. F. G. Eisenberg, D. A. Zagnoli and J. J. Sheridan III, J. Less-Common Met., 74, 323 (1980).

22. J. Mao, Z. Guo, X. Yu, H. Liu, Z. Wu, J. Ni, Int. J. Hydrogen Energy, 35(10), 4569 (2010).

23. J. Cermak, B. David, Int. J. Hydrogen Energy, 36(21), 13614 (2011).

24. M. Y. Song, S. H. Baek, J. -L. Bobet, and S. H. Hong, Int. J. Hydrogen Energy, 35, 10366 (2010). 